\title{
Arbitration and Protest in Hong Kong
}

Authors: Jie (Jeanne) Huang and Winston Ma

Following the promulgation of the judicial interpretation by the Supreme People's Court ("SPC") on 26 September 2019, Arrangement Concerning Mutual Assistance in Court-ordered Interim Measures in Aid of Arbitral Proceedings by the Courts of the Mainland and of the Hong Kong Special Administrative Region ("Arrangement") signed by Mainland China and Hong Kong on 2 April 2019 came into effect in Mainland China from 1 October 2019. This Arrangement provides mutual recognition and enforcement of interim measures between Hong Kong and Mainland China. It has generated broad coverage.[1] This post tries to add to the discussion by providing the first case decided under the Arrangement on 8 October 2019, and more broadly, the reflections on the continuing protests in Hong Kong and arbitration under “One Country, Two Systems'.

\section{Mutual recognition and enforcement of interim measures between Hong Kong and Mainland China}

Hong Kong Arbitration Ordinance has long been allowing parties to arbitral proceedings in any place to apply to the courts of Hong Kong for interim measures. Interim measures include injunction and other measures for the purpose of maintaining or restoring the status quo pending determination of the dispute; taking action that would prevent, or refraining from taking action that is likely to cause, current or imminent harm or prejudice to the arbitral proceedings; preserving assets; or preserving evidence that may be relevant and material to the resolution of the dispute. However, in contrast to the liberal Hong Kong counterpart, people's courts in Mainland China are conservative. Chinese law limits interim measures to property preservation, evidence preservation and conduct preservation. More important, Mainland courts generally only enforce interim measures in support of arbitration administered by domestic or foreignrelated arbitration institutions of the People's Republic of China (PRC). This is because Article 272 of Chinese Civil Procedure Law provides that where a party applies for a preservation measure, the foreign-related arbitral institution of PRC shall submit the party's application to the intermediate people's court at the place 
of domicile of the respondent or at the place where the respondent's property is located. Article 28 of Chinese Arbitration Law states that if one of the parties applies for property preservation, the arbitration commission shall submit to a people's court the application of the party in accordance with the relevant provisions of the Civil Procedure Law. Article 10 of Chinese Arbitration Law restricts arbitration institutions to those registered with the judicial administrative department of the relevant province, autonomous region or municipalities directly under the Central Government.[2]

There are few exceptions to the Mainland conservative approach. First, since 2017, ad hoc arbitration has been permitted in China's pilot free trade zones.[3] Therefore, Mainland courts are likely to issue interim measures in support of such ad hoc arbitration. Second, a party to a maritime arbitration seated outside of Mainland China can apply for property preservation to the Chinese maritime court of the place where the property is located.[4] However, the property to be preserved was limited to vessels, cargos carried by a vessel, and fuel and supplies of a vessel.[5]

The third exception is created by the recent Arrangement. Arbitral proceedings commenced both before and after 1 October 2019 are potentially caught by the Arrangement, under which property, evidence and conduct preservation orders could be granted by the courts in Mainland China to assist the Hong Kong arbitration.

The scope of the Arrangement confines to arbitral proceedings seated in Hong Kong and administered by institutions or permanent offices meeting the criteria under Article 2 of the Arrangement. Six qualified institutions have been listed on 26 September 2019, being Hong Kong International Arbitration Centre ("HKIAC"), ICC Hong Kong, CIETAC Hong Kong, Hong Kong Maritime Arbitration Group, eBRAM International Online Dispute Resolution Centre and South China International Arbitration Centre (Hong Kong). Future applications will also be considered and the list may be subject to alteration.

Articles 3-5 of the Arrangement set out the procedural requirements for applying to the courts in Mainland China for interim measures. Since time is of essence, application can be made by a party to the arbitration directly to the relevant Mainland Chinese court before an arbitration is accepted by an arbitration institution.[6] If the arbitration has been accepted, the application should be 
submitted by the arbitration institution or representative office.[7]

Article 8 of the Arrangement further reflects the importance of timeliness by demanding the requested court to make a decision after examining the application "expeditiously". Nevertheless, the Arrangement is silent on the specific time limit applicable to the court's examination process. Pursuant to Article 93 of the Chinese Civil Procedure Law, the court is to make an order within 48 hours after receiving an application for property preservation prior to the commencement of arbitration; Furthermore, Article 4 of the Provisions of the SPC on Several Issues concerning the Handling of Property Preservation Cases by the People's Courts demands the court to make an order within 5 days after the security is provided, and within 48 hours in cases of emergency.

The first case decided under the Arrangement demonstrates how "expeditiously" a people's court can make a decision. In the morning of 8 October 2019, the Shanghai Maritime Court received a property preservation application submitted by HKIAC. In this case, the arbitration applicant is a maritime company located in Hong Kong and the respondent is a company in Shanghai. They concluded a voyage charter party which stated that the applicant should provide a vessel to transport coal owned by the respondent from Indonesia to Shanghai. However, the respondent rescinded the charter party and the applicant claimed damages. Based on the charter party, they started an ad hoc arbitration and ultimately settled the case. According to the settlement agreement, the respondent should pay the applicant USD 180,000. However, the respondent did not make the payment as promised. Consequently, the respondent brought an arbitration at the HKIAC according to the arbitration clause in the settlement agreement. Invoking the Arrangement, through the HKIAC, the applicant applied to the Shanghai Maritime People's Court to seize and freeze the respondent's bank account and other assets. The Shanghai Court formed a collegial bench and issued the property preservation measure on the same date according to the Arrangement and Chinese Civil Procedure Law.

\section{Protests in Hong Kong}

As the first and so far the only jurisdiction with the special Arrangement through 
which parties to arbitration can directly apply to Mainland Chinese courts for interim measures, Hong Kong has been conferred an irreplaceable advantage while jockeying to be the most preferred arbitration seat for cases related to Chinese parties. Arbitration that is ad hoc or seated outside Hong Kong cannot enjoy the benefits of the Arrangement. Parties to an arbitration seated in Hong Kong are encouraged to select one of the listed institutions to take advantage of the Arrangement. Meanwhile, the Arrangement also attracts prominent international arbitration institutions to establish permanent offices in Hong Kong.

One may argue that the Arrangement is the necessary consequence of the "One Country, Two Systems" principle and the increasingly close judicial assistance between Mainland China and Hong Kong. Especially in the context of China's national strategy to develop the Greater Bay Area, the notion of "one country, two systems, three jurisdictions" makes Hong Kong the only common-law jurisdiction to deal with China-related disputes.[8]

However, to what extent may the recent protests negatively impact on the arbitration industry in Hong Kong? Notably, London and Paris have also experienced legal uncertainly (Brexit in the UK) and protests (Yellow vests movement in France) in recent years. Nevertheless, the Hong Kong situation is more severe than its western counterparts in two aspects. First, currently, the protestors have impacted on the traffic inside Hong Kong. Last month, they even blocked the Hong Kong airport. It is not surprising that parties may want to move the hearings outside of Hong Kong just for the convenience of traffic, if the arbitration is still seated in Hong Kong. Second, the continuation of protests and the uncertainty of the Chinese government's counter-measures may threaten parties' confidence in choosing Hong Kong as the seat for arbitration. The Arrangement brings an irreplaceable advantage to Hong Kong to arbitrate cases related with Chinese parties. However, this significance should not be overassessed. This is because by choosing a broad discovery and evidence rule, parties and tribunals have various means to deal with the situation where a party wants to hide a key evidence. Arbitration awards can be recognized and enforced in all jurisdictions ratified the New York Convention. Therefore, the value of the Arrangement is mainly for cases where the losing party only has assets in Mainland China for enforcement.

The flourish of arbitration in Hong Kong is closely related to Mainland China. However, Hong Kong, if losing its social stability due to the protests, will lose its 
arbitration business gradually. In the Chinese Records of the Grand Historian (Shiji by Han dynasty official Sima Qian), there is a famous idiom called "cheng ye xiao he bai ye xiao he".[9] It means the key to one's success is also one's undoing. It is the hope that Mainland China and Hong Kong can find a solution quickly so that the arbitration industry in Hong Kong can continue to be prosperous. This is more important than the implementation of the Arrangement.

Authors:

Jie (Jeanne) Huang is an associate professor at University of Sydney Law School, Australia, jeanne.huang@sydney.edu.au.

Winston Ma is an LLB student at University of Sydney Law School, Australia

http://arbitrationblog.kluwerarbitration.com/2019/07/24/arrangement-concerningmutual-assistance-in-court-ordered-interim-measures-interpretations-from-amainland-china-perspective-part-

i/?_ga=2.249539525.310814453.1570572449-887368654.1570572449.

[2] There are different opinions regarding whether Article 10 and 28 of Chinese Arbitration Law restrict the interim measures to arbitration administered by Chinese arbitration institutions. See the judgment of [2016] E 72 Cai Bao No. 427 issued by Wuhan Maritime Court. In this case, the Ocean Eleven Shipping Corporation initiated an arbitration in HKIAC against Lao Kai Yuan Mining Sole Co., Ltd. The applicant was a company in South Korea and the respondent a Chinese company. The parties had disputes over a voyage charter party. In order to ensure the enforcement of the coming award in Mainland China, the applicant applied to Wuhan Maritime Court to freeze USD 300,000 in the respondent's bank account or seizure, impound or freeze other equivalent assets. The People's Insurance Company provided equivalent insurance for the applicant's property preservation application. Wuhan Maritime Court permitted the property preservation application according to Article 28 of Chinese Arbitration Law and 
Article 103 of the Civil Procedure Law. However, this case is inconsistent with majority cases where Chinese courts rejected to issue interim measures for arbitration administered by ad hoc or arbitration institutions registered outside of Mainland China.

[3] SPC Opinions on Providing Judicial Safeguard for the Building of Pilot Free Trade Zones, Fa Fa [2016] No. 34, http://www.court.gov.cn/fabu-xiangqing-34502.html.

[4] Art. 21(2) of the Interpretation of the SPC on the Application of the Special Maritime Procedure Law of the PRC, Fa Shi [2003] No. 3.

[5] Ibid., art. 18.

[6] Art. 3 of the Arrangement.

[7] Ibid., art. 2.

[8] China has made the economic integration between the Grater Bay Area a national strategy. The Grater Bay Area includes Hong Kong, Macao and Guangdong Province https://www.bayarea.gov.hk/sc/outline/plan.html.

[9]

https://en.wiktionary.org/wiki/\%E6\%88\%90\%E4\%B9\%9F\%E8\%90\%A7\%E4\%BD\% 95\%EF\%BC\%8C\%E8\%B4\%A5\%E4\%B9\%9F\%E8\%90\%A7\%E4\%BD\%95. 